\title{
An(Other) truth: A feminist perspective on KPMG's True Value
}

\section{Christine Cooper \& Daniela Senkl}

Department of Accounting \& Finance, Strathclyde Business School, University of Strathclyde, Glasgow UK

This is a peer-review, accepted author manuscript of the following article: An(Other) truth : a feminist perspective on KPMG's true value. / Cooper, Christine; Senkl, Daniela. In: Sustainability Accounting, Management and Policy Journal, 16.08.2016. 
Purpose: Through a feminist lens, this study aims to provide insight into the ability of KPMG's True Value Approach to include "the other" in the corporate value creation process and into its potential to introduce a more "multiple" form of accounting. Additionally, this study seeks to set the True Value Approach within its broader social, economic and political context.

Design/methodology/approach: The study uses an interpretative analysis of KPMG's document "A New Vision of Value; Connecting corporate and societal value creation".

Findings: The KPMG document uses a language of fear of an external threat to promote its True Value Approach. It is revealed in this study that the concern of this approach is not to include "the other" in their valuation model unless it has an impact on corporate earnings. However, stakeholder actions or governmental regulations could be problematically reduced by the document's use of a language which suggests integration of "the other" and which might be perceived as socially progressive. It is found that the increase of societal or environmental value set out in the KPMG document depends upon "excessive" commodity production which uses up scarce environmental resources.

Research limitations/implications: The implication of this research is that the daunting problems of inequality and environmental destruction cannot be solved by initiatives like the KMPG True Value technology.

Practical implications: The essay argues that a feminine management or reporting framework would not need to fulfil the aim of managing the other in the sense of measurement and control since it is not based on the fear of loss. It would instead be an approach of giving and caring. A feminine alternative, however, is difficult to express in phallogocentric language. The ability to bring about change requires an ability to understand the prevalent symbolic order and the willingness to challenge it.

Social implications: The feminist perspective used in this essay to critically reflect on KPMG's True Value Approach and the neo-liberal economy in which it is embedded aims to create public awareness of the prevalent phallocentric symbolic order. Recognising the invisible power of the symbolic order is essential I order to be able to see how the new "integrative" management and reporting approaches are only slight modifications of the existing management and reporting tools. The essay highlights that these "alternatives" create the impression that business is dealing with the greatest global threats and can potentially be used to silence critics.

Originality/value: This essay contributes to existing critiques of integrated or shared value approaches by taking a feminist view. Even though corporate claims of "win-win situations" (in which environmental degradation and inequality can be solved as business opportunities) have been critiqued in the literature, this study adopts a rather unusual perspective (in accounting). This approach argues that initiatives grounded in the phallogocentric symbolic order are incapable of overcoming the current problems of our society; but they bear the risk of making the situation worse by creating a public impression that "someone is dealing appropriately with serious social and environmental issues". 


\section{Introduction}

The environment, the economy and society are constantly changing and this creates challenges for every citizen on the planet. In terms of the environment we are witnessing a myriad of challenges. To name a few (and in no particular order), we have ocean acidification, rising sea levels, soil erosion, habitat destruction, soil salination, water shortages, and radioactive contamination. In terms of society, it has been argued that the widening gaps in wealth and income within many countries are beginning to worry even the plutocrats (Bedoes, 2012). Indeed a World Economic Forum Report (2015), stated that

\section{....deep challenges remain, including poverty, environmental degradation, persistent unemployment, political instability, violence and conflict. These problems, which are reflected in many parts of this report, are often closely related to inequality.}

In terms of the economic, capitalism dominates the human beings and human worlds it organises (Brown, 2015). And, capitalism has begun to take an interest in the challenging social and environmental issues confronting the planet.

One form that this interest is taking is reflected in KPMG's recent initiative set out in its 2014 document entitled A New Vision of Value; Connecting corporate and societal value creation. This essay will consider this document through a feminist lens. This may seem a little unusual since there is a scant literature which considers social and environmental accounting from a feminist perspective (exceptions include Cooper, 1992; Phillips, 2014). Indeed an analysis of the document demonstrates that Cooper's (1992) warnings have gone unnoticed.

The paper will proceed as follows; the next section will consider the KPMG document in the context of other recent initiatives in this arena. In particular, this section considers Porter and Kramer's (2011) work on Shared Value, the International Integrated Reporting Council's Integrated Reporting Framework and the framework of the Natural Capital Coalition. The paper then turns to setting out its feminist theoretical framework drawing strongly from the work of Hélène Cixous. This section develops two aspects of Cixous's feminine theory - gendered language and the constitution of human understandings of ourselves and of our worlds. It then uses this framework to analyse the KPMG document. This section describes how the KPMG document is powerfully consistent with the dominant understandings of phallogocentric symbolic order of 2016 which promote a very "masculine" approach to eonomics. Finally, it sets out its conclusions.

\section{The True Value Approach in the context of recent initiatives to incorporate social and environmental elements}

The KPMG True Value Approach is a management concept which "focuses on linking societal value with corporate value" (KPMG, 2014, 4). It claims to be a tool measure and report on the value creation process of a company in the context of a new business landscape taking different environmental or social factors into account. KPMG (2014) states that challenges like overpopulation and climate change increase external pressures on companies. These pressures take the form of new regulations introduced by governments, unrest among workers, or changing climatic environmental requirements, and, if not managed properly will have a negative impact upon shareholder value and should therefore no longer be ignored by the companies. The True Value Approach claims to help companies identify potential new risk factors and new opportunities and encourages companies to create a business case in the context of this newly shaped business environment.

The True Value Approach appears to build upon other management research which aims to redefine value, among which the Shared Value (SV) concept of Michael Porter and Mark Kramer (2011) is arguably the most popular one. Both Shared Value and True Value agree that companies have paid little or no attention to societal issues (KPMG, 2014, p. 6; Porter and Kramer, 2011, p. 77) and that 
this has led to a disconnect between economic and social concerns (KPMG, 2014, p. 4; Porter and Kramer, 2011, 66). Each approach similarly concludes that the solution is to see environmental destruction and social inequality (or injustice) as a business opportunity.

A closer look at the two approaches demonstrates that the True Value Approach focusses more on the evaluation of risks than on opportunities, as it is mainly motivated by what it describes as "the threat of internalisation". According to the True Value Approach, action only needs to be taken as a consequence of outside "megaforces" rather than from the desire to create a healthier planet and an enhanced society. Opportunities can be realised by adjusting more quickly (or efficiently) than your competitors to outside threats. The Shared Value concept on the other hand does not emphasise the threats from governments, stakeholders or markets, it rather encourages businesses to be more proactive and to create a competitive advantage over others (who have not seen the need to address any particular social or environmental problems). In other words, the language used in the True Value approach is reactive, while the Shared Value concept comes across as proactive.

Another initiative which follows the idea of integrating environmental and social aspects into corporate value assessment is the International Integrated Reporting Council's (IIRC) Integrated Reporting Framework (IR) which was launched in 2013. The main idea underpinning this approach is that "value is not created by or within an organization alone". It therefore suggests that companies include both financial and non-financial factors, in the value assessment process. The IR framework is basically in line with the above mentioned approaches in that it states that "the purpose of looking beyond the financial reporting boundary is to identify risks, opportunities and outcomes that materially affect the organization's ability to create value" (IIRC, 2013, 20). The most obvious difference between the True Value Approach and the IR Framework is that the latter states that both qualitative and quantitative information are necessary to understand the value creation of a business whereas the former explicitly calls for the combination of traditional company financial figures and "monetized externality data" (KPMG, 2014, 47) although admitting that perhaps other currencies (their word) could be developed to measure social and environmental factors in the future.

A further related initiative hails from the Natural Capital Coalition. The Natural Capital Coalition describes itself as "a unique global multi-stakeholder collaboration that brings together leading global initiatives and organizations to harmonize approaches to natural capital." (NCC, 2016). Similar to the True Value Approach and the Shared Value concept, the Natural Capital Coalition calls for redefinition of the meaning of value. It introduces the term "integrated capitalism" by which it means that externalities need to be included to calculate the returns from financial, social and natural capital. It uses the terminology and elements of the approaches discussed above, but it does not foster an open discourse about them, and does not justify the creation of another approach. The Natural Capital Protocol Framework describes capitals in a similar way to the IR framework, except that it only addresses natural capital. The main driver for the development of the Natural Capital Coalition initiative seems to be the threat of a mandatory reporting requirement and the desire to be able to influence any regulatory initiatives. The Natural Capital Coalition is a business collective whose purpose is to collaborate and share methodologies in order to be able to "shape the future" according to the needs of business. In line with the True Value Approach (but different to the IR framework) the Natural Capital Protocol Framework focusses on quantifiable information and takes the view that you can only manage what you can measure.

In summary, the True Value Approach should be set within the context of a number of other initiatives which also claim to redefine value and extend the idea of value creation by taking the needs of society and the natural environment into account. While on the surface the initiatives might give the impression of being different, they are all "business-led" initiatives which are designed to enable business to have an input into potential future legislation and to control the framing of the debate. Their similarities are profound; they all adopt the language of financial economics (capital and value) and they are concerned with opportunities to make profits. Moreover, their approach of describing, for example, the environment as a "capital" means that it must be something which "produces a return", thus conceptually turning the environment into something from which we should profit. It might seem 
as if there are different alternatives to choose from but there aren't. Indeed, KPMG state that they "fully support the various initiatives" and even that they are "involved in many of them". The various initiatives create the impression of inclusivity by repeatedly using words like "true" (how could there be more than one truth?), "integrated" or "shared", but in the end they all come back to an increase in shareholder value or profit. It would be surprising if business and large accounting firm initiatives had any other end-goal, nor is it unexpected that each initiative uses very similar language and understandings of social and environmental issues. The next section, turns to the theoretical explanation of why there is so much "agreement" but how this agreed or taken for granted understanding of complex interrelated social and environmental problems may be problematic.

\section{A feminist framework}

The theoretical perspective adopted here will draw strongly from the work of Hélène Cixous (1976) and Cixous and Clement (1986). In terms of our analysis of KPMG's True Value Approach, this essay will draw upon two central aspects of Cixous's feminist theory. The first concerns language and the second, Lacanian/Freudian psychoanalysis.

For Cixous, alongside many other key $20^{\text {th }}$ century social theorists, language is a key to their theoretical perspective (see for example, Barthes, 1972; Derrida, 1973, 1976, 1978; Irigaray, 1974, 1977). For a whole movement of theorists, language does not simply function as a neutral means of "naming" the elements which constitute an "absolute reality". Language is far richer in that each word summons-up culturally important concepts. This can perhaps be seen easily in the use of language in advertising. The word "Chanel" in western society connotes concepts such as luxury, beauty and so on. Indeed, even "ordinary" words, for example "mother" are underpinned by concepts such as love, family, kindness and so on.

Twentieth century social theory further sees language as reflective of social structures and hierarchies (Schutz, 1962; Berger and Luckmann 1967). So, for example, in many cultures, a doctor is considered to be in a more prestigious occupation than a factory worker. The word doctor summons-up concepts different from those of factory worker. And different cultures and groups within cultures have different hierarchies. So, in some families the most important day of the week might be a Saturday, in others it would be a Friday and others a Sunday. The importance of this understanding of language is that it provides an explanation of how language not only reflects our worlds - but also shapes and creates them. Fairclough (1992, p. 64, cited by Livesey, 2002, p. 319) states that, language is "a practice not just of representing the world, but of signifying the world, constituting and constructing the world in meaning."

Articulated to her understanding of how language shapes our worlds, Cixous draws strongly from the work of Freudian psychoanalyst Jacques Lacan (1979) to argue that language shapes individuals too. Lacan adopts what might be described as a structuralist interpretation of Freud in that Lacan, alongside other contemporary social theorists sees humans as "constituted by language". This means that as young children learn to speak, they acquire culturally permeated language which informs them about the society they live in, its hierarchies and importantly about themselves. Lacan describes this as the symbolic order. So, one child might learn that they are the Australian son of an important lawyer, while another, the daughter of a Canadian hotel cleaner. Each child will understand its "place" in the world accordingly. Language is implanted into the unconscious and consequently provides a deeprooted (although changing) and culturally biased way of understanding the world. Humans "feel" what is "right" and "wrong". The power of the symbolic order is derived from it being invisible to people in their everyday lives as it is deeply enculturated from early ages (Thompson, 2008, p. 92).

Two points about the symbolic order are important in the context of this paper. First, it is continually shifting and changing. Second, the symbolic order is contested, and frequently those with the most power struggle to have the understandings which best serve their own private interests incorporated into the symbolic order. An example of this would be former British Prime Minister Margaret 
Thatcher's work in redefining "private industry" as progressive and dynamic, while redefining the industries owned by the state as cumbersome and inefficient. Under Thatcher, the state became the ugly sister (Czarniawska, 1985) while the private sector became sexy. This change in the symbolic order had material consequences in that, for example, it legitimised Thatcher's privatisation agenda.

It is through language that societal/cultural/familial "rules" (normally the rules of the most powerful) are inscribed on the unconscious. Language has been described as "logocentric" (Derrida, 1979). Logos is an important term in Western philosophy. In Greek, it has several meanings -- "a ground", "an account", or "a word". But it has come to have a more technical meaning -- a principle of knowledge and order. Therefore, logos can be described as the inward rational principle which we draw upon to make sense of, control and take charge of outward material things. The implications of this for accounting researchers is that it is important to recognise that institutions (e.g. KPMG, marriage, Celtic football club) themselves are not "neutral", but they are reflections of the contemporary logocentric symbolic order driven by the most powerful in society.

Helen Cixous accepting language's logocentrism builds upon the work of social theorist Jacques Derrida (1997). Derrida, starting from a Heideggerian point of view, argues that language contains dualistic oppositions, or in other words, that language functions as a fairly robust binary opposition system. These oppositions install a hierarchy that privileges one term over its binary opposite (for example, private over state; beautiful over ugly; presence over absence; rich over poor; happy over sad; opportunity over threat; strength over weakness and so on). We know what is superior and what to love and hate. Cixous (1975) alongside other writers (e.g., Benhabib, 1992; Butler, 1990; Kristeva, 1982) sees these binary opposites as being culturally determined as masculine and feminine. In the vast majority of cases, the masculine term is considered to be superior to the feminine one (for example strong/weak; positive/negative; rational/hysterical, single/multiple; reason/sentiment; relevant/irrelevant and so on), indeed, the "other" or subordinate binary opposition term is frequently seen as negative and/or powerless. Mother Nature serves as an excellent example of this. Phillips (2014) argues that recent contemporary cultural meanings have cast Mother Nature as dangerous and fickle ${ }^{1}$ or as frail and in need of male protection (see also Roach, 2003).

Both Derrida and Cixous describe a gendered binary opposition system of language as phallogocentric. Thus phallogocentric language provides a gendered "principle of knowledge and order" which is inscribed on individuals an enables them to make sense of and act in the material world. Phillips (2014, p. 444) argues that

\section{A common thread running through these dualisms is that what is categorized as authentically human conforms to ideas around idealized, hegemonic masculinity and is defined in opposition to what is taken to be natural, nature, or the physical or biological realm. The feminine, women and nature are rendered as abject; 'othered' to confirm and justify their subordination.}

While we live in a "gendered world", it is entirely possible for women to adopt "masculine" characteristics and vice versa. "Gender" is not interchangeable with "sex", however, several feminist writers (e.g. Irigaray, 1977; Thompson, 2008, p. 91) argue that the "bodily differences between women and men are the foundation of socially constructed gender differences that place men and maleness at the normative centre as the standard against which women and womanliness is compared". What is important here is that the most powerful in society have a large say in what constitutes the symbolic order and so are able to promote a "master identity" (Plumwood, 1991, 1993)

\footnotetext{
${ }^{1}$ Phillips (2014) further gives an example of how Mother Nature is portrayed in a long running advertising campaign for tampons in the US and the UK. These advertisements portray menstruation as a 'gift' from a malicious Mother Nature (a screeching, cackling, post-menopausal woman) who had to be outsmarted (see http://www.youtube.com/watch?v=9kDT3xmj9bU).

${ }^{2}$ While "sex" denotes the biological difference between men and women "gender" refers to the learned behaviours (roles) in a society or social group (ILO, 2007, p. 89).
} 
which is comprised of their own attributes. People who do not possess these attributes are constituted as sub-standard ("the other"). In our very powerful phallocentric order, male moral values are interpreted to be more based on rationality, rules and rights whereas female morale values are more based on relationships and care (Thompson, 2008, p. 92; Gilligan, 1982). There is a material dimension to this, for example, Thompson (2008) and Haynes (2016) argue that our current systems of rewards and constraints benefits men, both in terms of power distribution as well as financial gains.

The phallogocentric symbolic order in 2016 is constructed in a neo-liberal social, economic and political context. This means that the dominant values of neo-liberalism are constituted as masculine (e.g. profits = "masculine" and losses = "feminine"; and markets are masculine while social welfare is feminine). Western business language is often masculine and "reflects the desire of hegemonic control" (Livesey 2002, 338). It is traditionally characterised by "dualistic and hierarchical binary oppositions" (Phillips, 2014, p. 449, Haynes, 2016, p 7) where the masculine opposite is often considered as superior to the feminine.

Thus far it has been argued that the world and humans are constituted by phallogocentric language. As we learn to speak we acquire a host of gendered/culturally informed "rules and principles", an understanding of society's hierarchies and structures and about ourselves. The second important aspect of Hélène Cixous's theoretical perspective which is drawn upon here to analyse the KPMG True Value project is derived from the work of Lacanian/Freudian psychoanalysis on childhood development, especially in terms of their explanation of the split ego.

\section{The split ego and fear}

For Lacan, there are several key phases in a child's development. One, the "mirror stage", is derived from a critical reinterpretation of the work of Freud. In this phase, a child first "sees itself" (either in a mirror or through the reflection of their primary caregiver when the child notices and understands how that person reacts to them). This produces a psychic response that gives rise to the mental representation of an "I". The infant identifies with the image (gestalt), but the image in the mirror (or the reflection from another person), is always split into the "I" who is watching, and the "I" who is being watched. The unity and imagined control which the child's identification with its mirror image brings is imaginary. The "split ego" developed during the mirror phase means that the Lacanian subject will strive throughout the rest of their life for recognition. This can take the form of affirmation from others (through prizes, good performance evaluation, high salaries, admiring looks and so on). Indeed, we are incredibly vulnerable in our desire for recognition (Cooper, 1992, 2015; Roberts, 2001, 2009).

A second key phase in a child's development occurs when they acquire language. This happens at about the same time as the mirror phase. This stage reaffirms the split ego since one is never entirely "in charge" of one's own ideas - since, as explained earlier, on acquiring language the symbolic order ("others" order) is incorporated into the unconscious.

Freudian psychoanalysis adds a further dimension to Cixous's work. In terms of childhood development, Freud's Oedipal phase sets out that men are socialised by a fear of castration. Lacan agrees with Freud, at least in a symbolic sense. This sense of potential loss undergirds the masculine desire for recognition. Cixous and Clement (1986) argue that women are somehow deemed to have been "already castrated".

In summary, the Lacanian subject is an anxious one, with a split ego, imaginary relations, imprinted by the world through language. Due to their early development, people constantly strive for recognition - a confirmation of selfhood, through different strategies. Cooper (1992) argues that these include making those around us into mirrors, pretending to be in control of everything, and pursuing strategies designed to engender positive reflection from others. However, no amount of recognition can confirm one's self-hood, especially in a culture which places excessive emphasis on "great men" 
who are in possession of a "master identity" who always seem to be in control and not suffering from a split ego. Next this essay will briefly turn to what the theoretical perspective outlined here says about accounting before turning to our analysis of the KPMG True Value document.

\section{Logos and Accounting}

With its strong commitment to rules and principles, accounting is powerfully logocentric. Accounting (akin to language) is a system of rational principles which can serve to structure and make sense of outward material things. Accounting enables those in business a feeling of "mastery" - it provides them with a sense of being able to control the material world. For example, when faced with an uncertain future, managers can produce worst-case scenario budgets and so can plan for and be in control of all possible eventualities. And financial accounting can reduce complexity too - for example, it enables very complex financial instruments (with uncertain future cash flows) to be reduced to a monetary amount. Furthermore with its robust binary oppositions (debit/credit; profit/loss; asset/liability), accounting is phallogocentric, with one opposite dominating the other. It therefore feels like a natural, comfortable, understandable system. Accounting articulates well to the capitalist context; profits are good; losses are bad; assets are good; liabilities are bad. One of the most important financial ratios is the return on capital employed. So accounting can serve to ensure that we know how much returns are being made from capital.

When confronted by difficult and complex social and environmental problems, with the best will in the world, the only way the symbolic logic of accounting can function is to reduce these very complex multifaceted problems into financial debits and credits. Under neo-liberalism, capital is defined as that which makes a future income possible, and so, once anything is cast in terms of capital (for example, nature), it must produce a profit - and the bigger the profit which can be made from it, the better.

This section has set out the theoretical underpinnings which will be used to evaluate the KPMG True Value Approach. Recognising that KPMG is a large organisation which has a place in many different cultures and that its staff will have different social understandings the analysis will mainly contain itself to the "A New Vision of Value: connecting corporate and social value" document (KPMG, 2014).

\section{Analysis of the "A New Vision of Value: connecting corporate and social value" document}

On the face of it KPMG's True Value Approach appears to be an initiative which should be welcomed from a feminist point of view in that it is a method which is concerned with the "other" (the environment, employees, the state and so on). It gives the impression of promoting a seemingly more "multiple" form of accounting in that it tries to present a way of placing a monetary value on a "company's value creation that includes both corporate and societal value" (KPMG, 2014, p. 47). The approach includes values which we would applaud. For example, child labour and the discharge of hazardous chemicals into the water supply are negatives, while the living wage, recycling and training and education for employees are positives.

Binary oppositions and threats.

This positive/negative method of understanding the world reflects the overall position taken by KPMG's True Value Approach. It is a binary one which is dominated by an inside/outside dualism. 
The "inside" (individual companies) are under threat from the "outside/the other ${ }^{3}$." The whole point of the True Value approach is to provide a calculative technology to manage/control external threats.

Two main types of interrelated threats are identified in the document: The first is the increased scrutiny of business (from workers, communities, NGOs, consumers and so on) and the second is from what their document describes as "megaforces" which is taken to mean environmental issues like population growth, water resource depletion and so on. The first page of narrative states that -

... the role of business is increasingly being scrutinized, debated and challenged.... As a business community, we need to be aware of this trend and respond to it. We also need to be aware of the social and environmental megaforces at work, including our growing global population, the increasing scarcity of water and other resources, and changing weather patterns. (KPMG, 2014, p. 4)

According to the True Value document, the external threats are increasing and impacting on the cashflows of the business -- "historically, externalities have had little or no impact on the cash flows or risk profiles of most companies" (KPMG, 2014, p. 6). KPMG, understandably, is on the side of business. As a professional service firm KPMG is concerned with providing a service to the "insider".

This inside/outside binary opposition perspective serves to frame problems like climate change as being disconnected from the activities of business -

"the effects of negative externalities such as pollution, carbon emissions and ecosystem damage are becoming impossible to ignore as population growth and wealth growth drive consumption even higher" (KPMG, 2014, page 10) and "the climate is changing, ecosystems are declining and forests are disappearing" (KPMG, 2014, page 16).

Thus, any culpability for environmental destruction on the part of capitalist organisations is effaced. Climate change is happening to organisations rather than being created by them.

The KPMG approach makes clear that while megaforces are an underlying threat, the actual drivers of the threat are stakeholders and government. The challenge from stakeholders and government is risky and can impact upon the cash flows of the organisation -

“Actions taken by stakeholders such as workers, communities, NGOs and consumers over negative corporate externalities are also becoming more frequent, high profile and impactful. Such actions can have direct implications for cash flows and risk and as a result are driving more companies to look closer at their externalities and how they can be managed better" (KPMG, 2014, p. 11).

So, the "management" of externalities is not designed to make the world a better place; it is to protect organisational cash flows. In a very profound way this seems to reflect the phallogocentric masculine fear of loss.

A trope running through the document is that we are in the "age of internalization". So, for example, chapter 1 is headed "EXTERNALITIES: the age of internalization is here", and Chapter 2, "THREE KEY DRIVERS: increasing the rate of internalization". The KPMG document describes internalisation as a threat which is increasing -

"Companies need to better understand their so called 'externalities'. That is because what was 'external' is rapidly being internalized, whether through regulation such as taxes or

\footnotetext{
${ }^{3}$ Luce Irigaray, sees the internal/external body as more than symbolic. She sees it as grounded in men's and women's bodies.
} 
pricing, changing market dynamics including resource shortages, or more frequent and impactful stakeholder pressure" (KPMG, 2014, p. 4)

In short, business is under attack, and this attack is impacting on companies (or being internalised). From the perspective of social theory which takes the symbolic order seriously, this trope is interesting. Internalisation is the penetration of externalities into organisations. A phallogocentric symbolic order would suggest that penetration is something that men do to women - not the other way round. Symbolically, being penetrated makes a man into a woman, castrates him. And so must be resisted. KPMG see penetration as a negative because it might impact upon the cash flows of the organisation. But, outside pressure might actually be a "good thing" - perhaps enabling (or cajoling) business to act differently. Recent initiatives to force companies to pay their taxes or stop employing children serve as examples of this.

An understanding of the inside/outside dualism serves to reveal the importance of power in KPMG's true values. Externalities which have not been internalized or threaten to penetrate an organisation can be ignored. For example, if a company pursues poor health and safety practices but no-one ever complains and it does not threaten the company cash flows, then the company can carry on with their unsafe practices. Externalities which threaten to penetrate the organisation need to be managed and controlled. This is an extremely masculine approach which is fearful of losses (or reducing profits) and sets the neo-liberal opposition business/society firmly in place.

Indeed, it seems that the whole point of managing externalities, is to increase profit -

While internalization can bring risks to corporate value creation such as decreased earnings, higher costs of capital and reduced license-to-operate, there are also opportunities to create value, for example, through increased revenues or decreased costs. Businesses that anticipate new regulations, stakeholder actions and market dynamics will invest ahead of the curve to benefit from reduced risk exposure and potentially higher earnings as a result. (KPMG, 2014, p. 4)

Colby (1991, p. 209) points out that mislabelling (self-created) societal problems as something external enables people who create the problems in the first place to benefit from sorting them out afterwards without having to discuss the "faulty system of logic by which society makes its choices". The True Value Approach follows this logic. Some of the KPMG positives connote activities which would not be necessary except for the activities of companies. Take for example, the reduction in exposure to carbon tax or energy tax (see KPMG, 2014, p. 74). Such taxes have had to be set by governments to regulate companies. The benefit of reducing tax would not appear if companies did not over-pollute the atmosphere.

At this stage it is worth mentioning an important dualism which is not immediately apparent in the KPMG document. Traditionally, capital is intrinsically external to an organisation and so could be seen as another threat to be managed. Perhaps this might explain a paranoid attitude towards shareholders reflected in the obsession with maximising shareholder value in the short term.

In this section it has been argued that KPMG True Value document is founded upon a binary opposition system which privileges and makes the corporation dominant. However, while individual corporations are placed in a dominant hierarchical position, they also need to be fearful - they are under threat. Threat of penetration by undesirable others. This dualistic approach somehow absolves corporations from any responsibility for causing the threats (e.g. environmental destruction). The next section discusses KPMG's strategy for controlling the threats. 
KPMG's very simple solution to the problem of penetration and threats to corporate profits is to rationalise and quantify external threats -

"What executives need is a method to understand and quantify their externalities and the likelihood they will affect their company's earning capability and risk profile in the future" (p. 5)

The KPMG document classifies externalities into three types - economic, social and environmental and each of these can be either positive or negative. Although the document states that this framework should serve as a guideline which can be amended. Table 6 (KPMG, 2014, p. 43) provides a list of examples of positives and negatives in each of the categories. The categorisations reflect contemporary understandings of society. For example negatives in the social category include, "Failure to provide workers with a sustainable livelihood and good quality of life through underinvestment in living wages or through poor working conditions. Use of child labor" and "Damage to health, injury or death caused by underinvestment in health and safety safeguards".

In terms of wages, the description of the economic positive is "Provision of sustainable incomes and quality of life for workers". It is interesting that gender equality is not one of the True Value social positives, especially in light of the gender discrimination lawsuit against KPMG estimated to contain the names of more than 10,000 female KPMG employees, past and present, with more than 1,000 of those actively coming forward which has been on-going for the past five years (Simpson, 2016) ${ }^{4}$. Indeed, when scrutinized more carefully, there is no commitment to more equal pay, the curbing of excessive managerial remuneration and so on. In this respect, the values regarding workforce remuneration in the document cannot be described as socially progressive or radical.

Economic positives include "Contribution to societal wealth via returns to shareholders" and "Contribution to health of the financial services sector via loan interest". While these two very much reflect the status quo, KPMG's economic negatives are interesting - "Contribution to inefficiency in economies" and "Loss to the economy by not paying fair share of taxes". It is unclear what might constitute a "fair share", but KPMG offers "tax planning" services. On its website, it states that, with "proper tax planning and through identifying appropriate opportunities for tax savings, the tax a business bears can be optimized." it is debatable whether or not "tax savings" and "fair share" are commensurable.

This section has discussed the KPMG strategy in the document for dealing with external threats. The whole point of defining what constitutes an economic, social and environmental positive or negative is that each of them can be used as a supplement to the traditional accounting profit and give the "true value" created by an organisation. This will be considered next.

\section{True earnings, debits and credits}

The "true earnings" of a corporation is calculated by starting with the traditional accounting earnings figure and then making six adjustments - adding to the profit for social, environmental and economic positives and making deductions for social, environmental and economic negatives. Therefore, in order to calculate the "true earnings" of a company, the three categories have to be monetised. This is exemplified in the "true earnings bridge" (KPMG, 2014, p. 47)

Figure 1: KPMG earning's bridge

\footnotetext{
${ }^{4}$ http://www.accountancyage.com/2016/05/16/five-more-women-added-in-gender-discrimination-lawsuitagainst-kpmg-us/ accessed 29 July 2016.

${ }^{5}$ https://home.kpmg.com/sg/en/home/services/tax/tax-planning-and-compliance/tax-planning-andcompliance.html accessed 29 July 2016.
} 


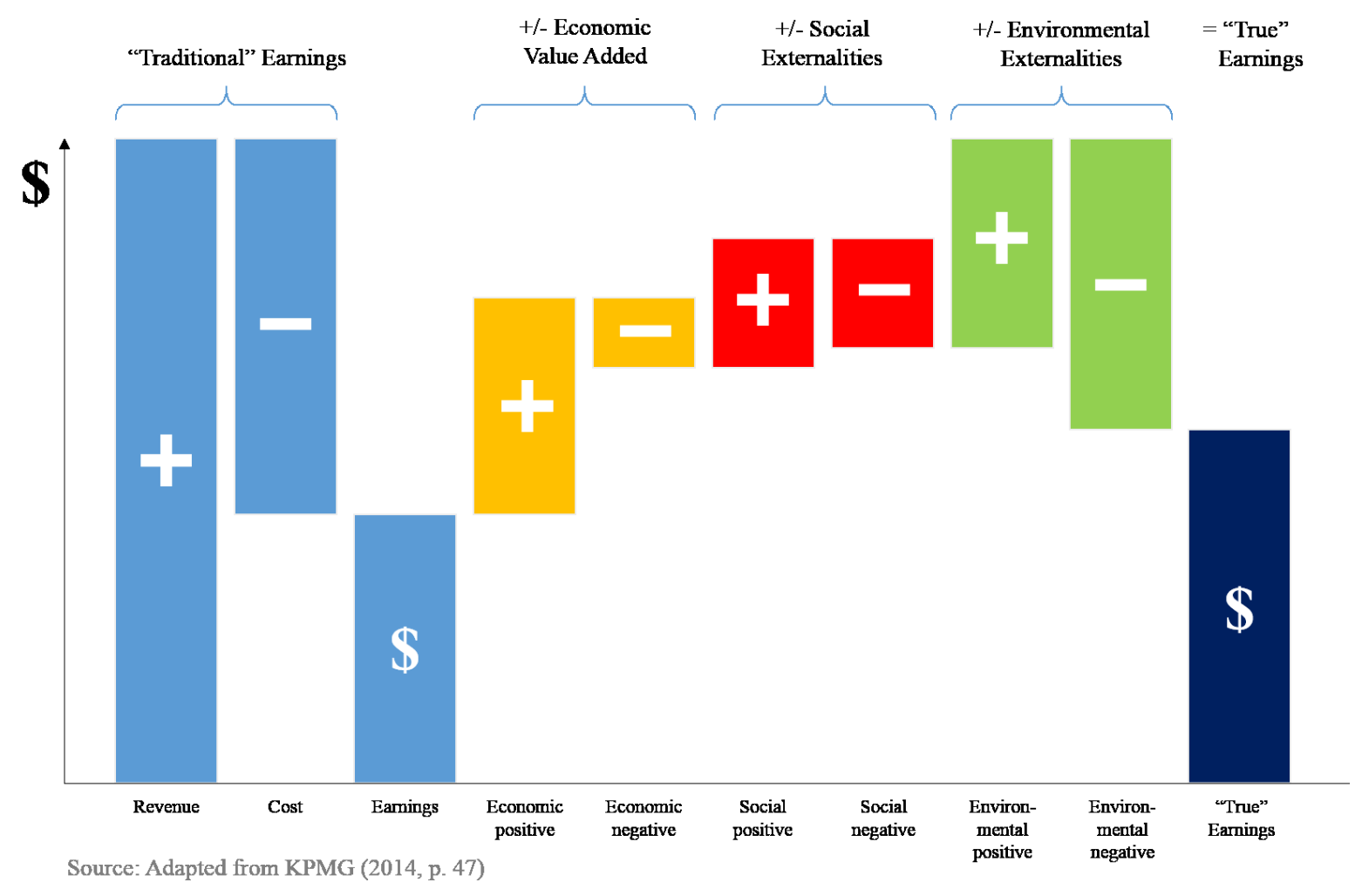

The KPMG document does recognise that there are limitations to monetizing the positives and negatives but nonetheless it states that

Monetization provides a common metric through which a company can more easily understand, compare and contrast the magnitude of its various externalities. Furthermore, given that the ultimate goal is to develop strategies that create both societal and corporate value, then there are clear advantages in using the same metrics to express both. Perhaps most importantly, the use of financial metrics to quantify externalities enables social and environmental factors to be brought into decision making in terms that business managers are already familiar with. (KPMG, 2014, p. 44)

The binary opposition of positives and negatives of KPMG's true value technology could be seen as a gesture towards its vision of the perfection of the double entry system -

... monetization forms the starting point of KPMG's True Value methodology as well as initiatives from other organizations.

However, monetization is not necessarily the ultimate solution. We might end up with a more complex and multi-lensed approach to evaluating business performance, in which case the goal must be to develop a standardized approach that aligns more closely with the elegance of the double-entry financial accounting system.

The double-entry system, in which every debit must have a credit and every credit a debit, continues as the basis of financial accounting even though standards have been added over time to define particular debits and credits. (KPMG, 2014, p. 44)

The desire for a double-entry book-keeping for the economic, social and environmental capitals, albeit in non-monetary form (although it is difficult to imagine what other currency might be used) must be 
seen as a desire to consolidate the current symbolic order and enable a feeling of security and control. Both monetization and/or the use of other currencies and double-entry book-keeping are an oversimplification and extremely reductionist. The forcing of very complex and interrelated phenomena (like quality of life and global warming) into a system like KPMG's True Values or a double-entry system can only serve to minimize, obscure, and/or distort them. We have already described how the internal/external opposition serves to obscure business's role in global warming. And the placing of monetary values on human suffering can only serve to obscure the awfulness of it.

The two previous sections describe the technological framework of KPMG's true values document and how it moves from the accounting profit to a "true profit". While it is hard to disagree with some of the positives and negatives of the three categorisations, they are not radical in the sense of demonstrating a commitment to equality, and are rather opaque in their understanding of "fairness". But much more importantly, they are extremely reductionist. We believe it is a mistake to propose that very complex phenomena can be reduced to numerical debits and credits. Crittenden (2000, p. 59) argues that doing so will "reduce ability to feel for others by turning them into objects, distancing oneself from them emotionally, and considering them lesser and thereby exploitable". Double entry book-keeping may help to make people feel in control but will fail to enable people to understand very complex issues and render them emotionally distant. Moreover, the desire to profit from complex social and environmental problems may well make the problems worse. The next section will turn to an explanation of how the neo-liberal symbolic order is configured to make returns from capital appear to be natural and inevitable and the implications of this for "human capital" as set out in the Integrated Reporting framework discussed earlier.

\section{Neo-liberal symbolic order and inequality}

The KPMG document asserts that, through their double-entry system, the aim should be to have one accounting standard for accounting for "societal value creation". The document suggests that the International Integrated Reporting Council's (IIRC) framework is a good point of departure in that it identifies six types of capital (or 'stores of value') that a company needs to create corporate value. These capitals are financial, manufactured, intellectual, human, social and natural.

The comments in the KPMG document reflect and support the neo-liberal symbolic order. This can be exemplified by using the approach to humans (or in KPMG's words "human capital"). The document states that -

Take, for example, human capital or the stock of employee knowledge and capabilities that a company has access to but is actually owned by the employees in question. In an ideal world, there would be an accepted way to measure the value of that human capital that takes into account the experience, skills, values and motivation of employees.

A profit and loss account for human capital would be able to demonstrate whether the company has either increased or devalued its stock of human capital over the year by increasing or devaluing the experience, skills, values and motivation of its people. (KPMG, 2004, p. 45)

The idea of a "profit and loss account for human capital" is strange given the context of a sentence which also mentions an increase or a decrease in the stock of human capital. Stock is normally an asset and capital is normally a credit (a form of liability). Stock is owned and controlled by a company; but, while an organisation can to some degree control its workforce - it does not "own" it. And, is human capital the same as, for example, financial (or share) capital? Can the double entry system efface their differences by treating both as credits?

\footnotetext{
${ }^{6}$ It is striking that human capital and intellectual capital are made into distinct categories. Is it possible to have intellectual capital without humans?
} 
Michel Foucault's (2008) work provides an insight into the neo-liberal symbolic order rationalisation of human capital. He posited that if, under neo-liberalism, capital is defined as that which makes a future income possible, then for human capital the income is the wage: "Ability to work, skill, the ability to do something cannot be separated from the person who is skilled and who can do this particular thing" (p. 224). Human capital (or a worker) produces income streams, both for themselves, since all capital should make a return, and also for their employers.

Foucault's (2008) work also sets out an explanation of the neo-liberal symbolic order's rationality in terms of the value of different human-beings (or human capital). According to neo-liberal rationality, human capital includes both genetic and acquired elements. Some human capital is genetically or biologically superior to other human capital; and some human capital units (or their parents) invest different amounts in themselves through education, working out at the gym and so on. So, inequality, not equality, is the medium and relation of human capital. When we are constructed as human capital in a neo-liberal symbolic order, equality ceases to be our presumed natural relation with one another (Brown, 2015). Humans are not purely valuable as humans. In effect, from a True Value perspective, the value of human-beings is in their productive abilities and each has different capacities which can be measured and quantified. True Values can create a hierarchy of humans ranked according to their different attributes (skills, motivation and so on). It is therefore unsurprising that wage equality is not considered by the KPMG True Value document. According to the contemporary symbolic order, people are unequal, and their pay should reflect this.

This understanding has implications for the gender pay gap. If the symbolic order is a phallogocentric one which devalues the feminine and/or outsiders (ethnic minorities and so on), while at the same time, accepting that humans have different values, then women and other "outsiders" will automatically be considered to be less valuable than their masculine counterparts. Jean Baker Miller expresses this by arguing that women are defined differently to men and that the differences are defined as deficiencies (Miller, 1986, cited by Thompson, 2008, p. 91). Earlier work in gender and accounting described the representation of women in annual reports as being influenced by capitalism (women as consumers and a reserve army of labour) (Tinker and Neimark, 1987). While acknowledging that patriarchy needs to be understood in the context of the imperatives of the economic system, Adams and Harte (1998) argue that the role of patriarchy is still important. Although Tinker and Neimark (1987) and Adams and Harte (1998) may have had some disagreement in terms of the drivers of inequality, both have a strong commitment to equality and thus stand against the neo-liberal perspective on human capital outlined here. More recently, Haynes (2016) points out that "in a post-feminist climate where women's belief that they are equal means that ongoing sources of inequality are ignored, rendered invisible and have become increasingly difficult to name." (p. 4). Feminist issues have been trivialised and the voices of the critics of patriarchy have been diminished. In the KPMG document, equality is not on the agenda.

This section has briefly analysed the KPMG document's desired move from its True Values to a unified system of "social value creation" suggesting that the International Integrated Reporting Council's (IIRC) framework is a good point of departure. It is argued that this serves to demonstrate KPMG's embrace of the neo-liberal symbolic order and thus presents a powerful obstacle for those who believe that humans are equal and should be treated so. The next brief section, continues the concern with the ways in which KPMG's True Value Approach is reflective of the symbolic order.

\section{Commodity production and profitability}

The True Value document appears to be based upon the assumption that commodity production is "neutral". The example of an electronics manufacturer is given, in which, the "company's products provide benefits to society by being used to reduce energy consumption, deliver learning and education and/or provide medical services" (KPMG, 2014, p. 13). In this case, the company's products may well fulfil important social functions, but overall, if the threat of global warming and 
the enhancement of the quality of life of the world's citizens, is to be taken seriously, commodity production may need to be attenuated. The world's resources are being depleted at an alarming rate. Yet, in the contemporary symbolic order, it would be "illegitimate" for a professional service firm to suggest that its clients stop production, stop creating demand for products which we do not need or are bad for us, and question the short termism of shareholder value maximisation.

It seems as if the KPMG document is proposing that large corporations can pretty much carry on with commodity production, the drive to increase profits and now even to profit from environmental and social devastation while at the same time solve this devastation. Livesey $(2002$, p. 339) argues that such win-win discourses fail "to challenge in any fundamental way the taken-for granted truths about the nature of markets, competition, and economic actors" (see also Milne et al., 2009, p. 1213 for a similar argument). In her analysis of Shell's "report to society" Livesey (2002, p. 339) comes to the conclusion that they "continued to advocate for the free-market system, downplaying in particular its inability to account for social justice and environmental quality." The True Value Approach of KPMG demonstrates the same inability to challenge the profit motive and commodity production in itself ${ }^{7}$. In the next section we develop this point further in the context of KPMG's role as a provider of Professional Services to clients.

\section{The selling point of True Values}

The KPMG document recognises that there are other approaches to social and environmental accounting when it states that "Many of the current initiatives aim to help companies measure their social and environmental impacts and some focus primarily on negative impacts. While this is a valuable first step, KPMG has identified a need for an approach that is better balanced and helps enable companies to go further." (KPMG, 2014, p. 35). In other words, KPMG has devised a product which can be used to resist some of the threats generated by stakeholders ("explosion of the global middle class", p. 6) by revealing the "positive" side of business.

Moreover, in a complex threatening world, the approach set out in the True Value document, appears to be one which offers the hope of "doing something" and "moving in the right direction". Milne et al. (2006) note that the language used in corporate sustainability reports often uses the metaphor of going on a journey towards sustainability. This creates the perception of being active but without having to define a specific destination and without having to be radical in terms of dramatically changing business practices. This is described as amplifying weak sustainability rather than strong sustainability (p. 803). Although the KPMG True Value document places more emphasis on the defence against an external threat rather than a proactive self-determined journey; it sets out a technology, which if adopted by smart businesses - can be used as a new business opportunity. They tell a value creation story. In other words, the document provides a business case for sustainability which claims to create a win-win situation for business and society (Banjeree, 2002; Livesey, 2002; Milne et al., 2009).

The language of the KPMG document implies that it has developed a new way of thinking about environmental and social problems (see for example Prasad and Elmes, 2005, p. 849) and it could be referred to as a paradigm shift (Banerjee, 2002, p. 178; Colby, 1991, p. 193; Milne et al., 2009, p. 1214), but it is not. Colby (1991) describes the evolution of five economic paradigms from which the eco-development paradigm is the most advanced paradigm in terms of the level of integration of economic, environmental and societal systems in the definition of development and the organisation of our society. This paradigm is a synthesis of the "unrestrained exploitation" paradigm (Frontier Economics) and the "back to the nature" paradigm (Deep Ecology) (Milne et al., 2009; Colby, 1991; Prasad and Elmes, 2005). The eco-development paradigm comprises the idea that neither humanity nor nature is superior to the other (Colby, 1991, p. 207). However, without a genuine commitment to such a synthesis, a new paradigm "may not in fact represent distinct sets of values and beliefs, but be

\footnotetext{
7 If "the environment" is perceived as a business opportunity, then increasing commodity production could help to enhance this opportunity.
} 
more or less variants of the existing ones" (Milne et al., 2009, 1217). We would argue that the True Value document is firmly embedded according to the symbolic order and so does not (sadly) represent a paradigm shift. Indeed the newly introduced business language which portray companies as "integrative", "sharing" and "sustainable" are acceptable only if they do not disrupt of the balance of power (Milne et al., 2006, 812). Worse, seemingly new paradigms "serve the function of legitimating or justifying courses of action.” (Milne et al., 2009, 1217).

This section has argued that the KPMG document has promoted a way for organisations to "show their positive side", perhaps to deflect attacks from external stakeholders. Moreover, in a complex and challenging environment the True Value Approach holds out the possibility of, at least, moving forward (in the right direction). The language in the document gestures towards it setting out a paradigm shift. It is argued that the document is more a close adherent to existing values and beliefs and very much shaped by the symbolic order. The final section of analysis turns to the pictures in the report which serve to demonstrate the document's commitment to the neo-liberal phallogocentric symbolic order.

\section{The inside/outside and profit in pictures}

There is a small but insightful literature which considers the profusion of visual images in accountingrelated media. While adopting different theoretical perspectives to inform their analysis of the pictures and their performativity, this research is unanimous in its understanding of images as powerful communication devices (see for example, Benschop, and Meihuizen, 2002; Bernardi et al, 2005; Davison, 2007, 2008, 2009, 2010, 2011, 2014; Duff, 2011; Duff and Ferguson, 2007; Graves, et al, 1996; Hopwood,1996; and Justesen, and Mouritsen, 2009; Kuasirikun, 2011; Preston et al 1996; Preston and Young, 2000; Tinker and Neimark, 1987)

Davison (2014) argues that visual images matter because: (1) pictures are ubiquitous; (2) pictures are multi-faceted, carry complex and co-existing messages, and are open to rich and varied interpretation; (3) pictures have interwoven roles as incremental information and impression management (or representation and construction); (4) pictures have a special place in memory and cognition; (5) pictures have emotional power.

The images in KPMG's document ${ }^{8}$ are powerful and interesting in terms of the theoretical framework set out here. This document contains two dominant forms of photographs. One of the forms largely consists of people in business attire (mainly men) working in modern corporate offices, frequently with their charts, graphs or tablets. These pictures are predominantly infused with cool "KPMG blue". The colour in the photographs gives the impression of order and calmness. The pictures themselves connote various forms of rational analysis - charts, graphs, discussion and so on. The cool-blue pictures are juxtaposed with the second form of pictures which are in the main colourful and vibrant images of people working in typically non Anglo-Saxon cultures. The "non-KPMG" images give the impression of heat, chaos and irrationality.

The images support the inside/outside binary opposition set out in the text and serve to reinforce the depiction of KPMG (and business in general) as advanced, methodical, ordered and rational. The pictures further suggest that the world is rich, vibrant, uncertain, challenging, and perhaps threatening (there are pictures of demonstrations). But, KPMG can provide the technologies to bring about control and order.

Perhaps the most important picture is the one on the cover (see appendix 2). It is a diagram which appears to be emanating from a computer screen depicting some kind of network. The largest and central node contains a \$ symbol. This implies that money remains central to the KPMG vision and

\footnotetext{
${ }^{8}$ https://www.kpmg.com/Global/en/topics/climate-change-sustainability-services/Documents/a-new-vision-ofvalue.pdf
} 
that the whole point of taking on board threats to the organisation through the application of KPMG's true value technology -- is to make money.

In this brief section we have argued that the pictures in the document resonate powerfully with the text in their placement of money at the centre and in their emotional representation of the binary opposition us/them. We now turn briefly to our discussion and conclusions.

\section{Discussion and conclusion}

Drawing on the theoretical framework developed by Hélène Cixous we have analysed the KPMG True Value document. The document articulates with the contemporary phallocentric symbolic order which, itself, is constructed in a neo-liberal social, economic and political context. The symbolic order is mainly invisible to society, yet, it is deeply embedded in our culture and language. In the current phallogocentric symbolic order the masculine "master identity" is consciously or unconsciously considered to be superior. Cixous sets out a case that the symbolic order can be revealed through the dualistic and hierarchical binary oppositions and the desire for control.

Hines, (1992, p. 314) powerfully argues that, in terms of accounting, the masculine master identity manifests itself in the creation of a linear and divisible world of debits and credits to measure and control reality. The KPMG True Value document attests to this in that it is concerned with controlling threats through classification, quantification and coding (debit/credit). In addition, it is concerned with making profit from the newly categorised "economic, social and environmental problems". While the practices set out in the document "feel right" since they articulate with the symbolic order, it is surely a mistake to use the same technologies which are at least in part culpable for some of the worst excesses of capitalism (the creation of demand for unnecessary products; child labour; environmental destruction; the destruction of communities by the closure of factories and other industries and so on) in order to try to solve these self-same problems.

In keeping with its articulation to a masculine master identity, the document is based upon fear - a masculine fear of loss - in this case a loss of cash or profits. To be in fear in 2016 when the world is confronted by so much horror is totally understandable - but in the face of all the threats which we are facing, to fear the loss of profits seems a little strange. However, the symbolic argument set out here would suggest that masculine fear is rooted in the fear of castration so constant assurance is required that man has the power to penetrate rather than being penetrated. Moreover, in a capitalist system profits are incredibly important - so their loss will be felt very keenly. Within the predominant phallocentric symbolic order profit brings the necessary assurance through power and recognition and has therefore to be maximised. The document is also grounded in a fear of the "other" and is entrenched in a phallogocentric binary opposition framework in which business is construed as the dominant term and as a form of master identity. The binary opposites (the other) set out in both the words and the pictures in the document were constructed as deficient, threatening and different - in other words, feminine. Indeed, one of the points of adopting a True Value Approach would seem to be the silencing of the threatening other. An ecofeminist position would do the exact opposite it would position "virtue and compassion over the egocentric profit motive, and insist[ing] that the voices of the oppressed and marginalized peoples be fully represented in moral decisions (which includes both economic and political decisions)" Crittenden (2000, p. 57). There is potentially another group which the document might attempt to silence. Milne et al. (2009, p. 1213) argue that initiatives like the KPMG True Value Approach may well serve to take the wind out of the sails of real environmentalists. Therefore, overall KPMG's True Value Approach could serve as a technology which, if adopted by a company, would present an image of that company as kind, compassionate and actively seeking to "do their best" to save the planet and treat humanity with dignity. In this sense the adoption of the KPMG True Value technology may serve as a strategic manoeuvre to silence any criticism. Indeed, there is no recognition of the role of business in creating any of the problems which the world faces. In light of this, the KPMG document should be viewed with deep concern. 
Overall it is argued that the KPMG True Value Approach is a consequence of the predominant phallocentric symbolic order and that any attempt to include the other (however serious it might be) is extraordinarily difficult. The approach is not radical in the sense that it does not challenge the predominant phallocentric symbolic order itself. A serious alternative management or reporting framework has to challenge the predominant phallocentric symbolic order itself - otherwise it would just join the numerous indistinguishable initiatives some of which are discussed in this essay. The feminist case set out here is that it is essential to understand that we can only be freed from the contemporary destructive masculine domination and destruction of Mother Nature if we reject the predominant symbolic order and the desire to relieve the fear of castration through profit

maximisation. The goal of profit maximisation is never ending, because the relief it brings is fleeting, and has to be constantly renewed through excessive production. So business is caught in a cycle of having to create increasing levels of demand for its products (through advertising and so on) with little regard for the environmental havoc created by this; while at the same time reducing its costs of production, its tax liabilities and payments to its former employees (their pensions and other health benefits).

But what might an alternative look like? It is difficult to express or even imagine a feminine approach in the predominant phallogocentric language (Cooper, 1992). Cixous (1981) discusses a feminine (libidinal) economy which according to Cooper (1992, p. 37) "would not be concerned with profits and [would] even [be] less afraid with loss; it would be concerned with gifts, what was given; it would contain no phallocentric economic terms; and it would not be competitive". A feminine approach would address the question of what would be the contribution of a business to society if profit (or even money) did not exist. In absence of the fear of loss there would be no need for recognition, suppression of the other and the assurance of having the biggest or largest (whatsoever). Consequently profit (and the maximisation thereof) would not create joy or relief.

According to a feminist perspective, the pretence of control which is offered by management and reporting frameworks such as the KPMG True Value Approach is driven by the conscious or unconscious constant threat of the outside unpredictable, unmeasurable and uncontrollable other. When this is recognised an alternative approach of inclusion and care can develop. Byrch et al. (2015) come to the conclusion that when the tension between environmental concerns and economic growth are readily acknowledged the seeds of hope of alternatives will develop.

In light of the arguments provided in this essay it would seem appropriate to consider strategies for changing the symbolic order into something more feminine. A feminine alternative would be based on the gift rather than the return. In a feminine economy there would be no difference between taking and giving - they would be of the same quality. It would therefore not be necessary to account for them separately. The driver for profit maximisation and wealth accumulation would not exist in a feminine economy and as there would be less desire to control. But of course, as has been argued here, the necessary precondition to allow for an alternative approach to develop is to truthfully acknowledge the power of the prevalent symbolic order. As an inspiration for a feminine approach of care and giving the essay will conclude with the words of Hélène Cixous.

She gives. She doesn't know what she's giving, she doesn't measure it; she gives, though neither a counterfeit impression nor something she hasn't got. She gives more, with no assurance that she'll get back some unexpected profit from what she puts out. She gives that there may be life, thought, transformation. This is an "economy" that can no longer be put in economic terms. Wherever she loves all the old concepts of management are put behind. At the end of a more or less conscious computation she finds not her sum but her differences (Cixous, 1981, p. 264). 


\section{References}

Adams, C., and Harte, G., (1998), The changing portrayal of the employment of women in British banks' and retail companies' corporate annual reports, Accounting, Organizations and Society, Vol. 23 , No. 8 , pp. $781-812$

Banerjee, S. B. (2002), "Corporate environmentalism: the construct and its measurement", Journal of Business Research, Vol. 55 No. 3, pp. 177-191.

Barthes, R., (1972), Mythologies, Paladin, London.

Beddoes, Z M. (2012), "For richer, for poorer: Growing inequality is one of the biggest social, economic and political challenges of our time", The Economist, available at: http://www.economist.com/node/21564414 (accessed 4 August 2016).

Benhabib, S. (1992), Situating the Self: Gender, Community and Postmodernism in Contemporary Ethics. Polity, Cambridge.

Benschop, Y. and Meihuizen, H.E. (2002), "Keeping up gendered appearances: Representations of gender in financial annual reports", Accounting, Organizations and Society, Volume 27, No 7, pp. 611-636.

Berger, P. L and Luckmann, T. (1967), The Social Construction of Reality: A Treatise in the Sociology of Knowledge, Penguin Social Sciences, London.

Bernardi, R.A., Bean, D.F. and Weippert, K.M. (2005), "Minority membership on boards of directors: The case for requiring pictures of boards in annual reports", Critical Perspectives on Accounting, Volume 16, No 8, pp. 1019-1033.

Brown, W. (2015), Undoing the Demos: Neoliberalism's Stealth Revolution, Zone Books, New York.

Butler, J. (1990), Gender Trouble, Routledge, London.

Byrch, C., Milne, M.J., Morgan, R., Kearins, K. (2015), "Seeds of hope? Exploring business actors' diverse understandings of sustainable development", Accounting, Auditing \& Accountability Journal, Vol 28, No 5, pp. 671-705.

Cixous, H. (1976), “The Laugh of the Medusa”, Signs, Vol. 1, No 4, pp. 875-893.

Cixous, H. (1981), “Le Sexe ou la Tete”, (A. Kuhn, Trans.), Signs, Vol. 7, No 1, pp. 41-55.

Cixous, H., and Clement, C. (1986), The Newly Born Woman, University of Minnesota Press, Minneapolis.

Colby, M. E. (1991), "Environmental management in development: the evolution of paradigms", Ecological Economics, Vol. 3, No 3, pp. 193-213.

Cooper, C., (2015), "Entrepreneurs of the self: The development of management control since 1976", Accounting, Organizations and Society, Vol. 47, November, pp. 14-24.

Cooper, C., (1992), "The Non and Nom of Accounting for (M)other Nature", Accounting, Auditing and Accountability Journal, Vol. 5, No, 3, pp. 16-39. 
Crittenden, C. (2000), "Ecofeminism Meets Business: A Comparison of Ecofeminist, Corporate, and Free Market Ideologies”, Journal of Business Ethics, Vol. 24, No 1, pp. 51-63.

Czarniawska, B. (1985), "The ugly sister: On relationships between the private and the public sectors in Sweden”,. Scandinavian Journal of Management Studies, Vol. 2, No 2, pp. 83-103.

Davison, J. (2007), "Photographs and accountability: Cracking the codes of an NGO", Accounting, Auditing \& Accountability Journal, Vol. 20, pp. 133-158.

Davison, J. (2008), "Rhetoric, repetition, reporting and the 'dot. com' era: Words, pictures, intangibles”, Accounting, Auditing \& Accountability Journal, Vol. 21, № 6, pp. 791-826.

Davison, J. (2009), "Icon, iconography, iconology: Visual branding, banking and the case of the bowler hat", Accounting, Auditing \& Accountability Journal, Vol. 22, No 6, pp. 883-906.

Davison, J. (2010), “(In)visible (in)tangibles: Visual portraits of the business élite”, Accounting, Organizations and Society, Vol. 35, No 2, pp. 165-183.

Davison, J. (2011), "Barthesian perspectives on accounting communication and visual images of accountancy", Accounting, Auditing \& Accountability Journal, Vol 24, No 2, pp. 250-283.

Davison, J. (2014), "Visual rhetoric and the case of intellectual capital", Accounting, Organizations and Society, Vol. 39, No 1, pp. 20-37.

Derrida, J. (1997), Of Grammatology, The Johns Hopkins University Press, Baltimore.

Duff, A., (2011), "Big four accounting firms' annual reviews: A photo analysis of gender and race portrayals”, Critical Perspectives on Accounting, Vol. 22, No 1, ,pp. 20-38.

Duff, A., and Ferguson, J. (2007), "Disability and accounting firms: Evidence from the UK", Critical Perspectives on Accounting, Vol. 18, No 2, pp. 139-157.

Foucault, M. (2008), The Birth of Biopolitics: Lectures at the Collège de France, 1978-79 (G. Burchell, Trans.), Palgrave Macmillan, Houndmills, UK.

Graves, O. F., Flesher, D. L., and Jordan, R. E., (1996), "Pictures and the bottom line: The television epistemology of U.S. annual reports", Accounting, Organizations and Society, Vol. 21, No 1, pp. 5788 .

Gray, R. (2006), "Social, environmental and sustainability reporting and organisational value creation?", Accounting, Auditing \& Accountability Journal, Vol. 19, No 6, pp. 793-819.

Haynes, K. (2016), “Accounting as gendering and gendered: a review of 25 years of critical accounting research on gender", Critical Perspectives on Accounting, forthcoming.

Hopwood, A. (1996), "Making visible and the construction of visibilities: Shifting agendas in the design of the corporate report: Introduction", Accounting, Organizations and Society, Vol. 21, No 1, pp. 55-56.

IIRC (2013), The International <IR $>$ framework, available at: http://integratedreporting.org/wpcontent/uploads/2013/12/13-12-08-THE-INTERNATIONAL-IR-FRAMEWORK-2-1.pdf, accessed 3 August 2016. 
ILO (2007), ABC of women workers' rights and gender equality, $2^{\text {nd }}$ ed., International Labour Office, Geneva, available at: http://www.ilo.org/wcmsp5/groups/public/---dgreports/--gender/documents/publication/wcms_087314.pdf, accessed 17 August 2016.

Irigaray, L. (1974), Speculum of the Other Woman, (G.C. Gill, Trans.), Cornell University Press, Ithaca, NY.

Irigaray, L. (1977), This Sex Which Is Not One, (C. Porter, Trans.), Cornell University Press, Ithaca, NY.

Justesen, L., and Mouritsen, J. (2009), "The triple visual: Translations between photographs, 3-D visualizations and calculations", Accounting, Auditing \& Accountability Journal, Vol. 22, No 6, pp. 973-990.

KPMG (2014), A New Vision of Value, available at: https://assets.kpmg.com/content/dam/kpmg/pdf/2014/10/a-new-vision-of-value-v1.pdf, accessed 3 August 2016.

KPMG (2015), Introducing KPMG True Value, available at: https://www.kpmg.com/Global/en/topics/climate-change-sustainabilityservices/Documents/introduction-kpmg-values.pdf, accessed 3 August 2016.

Kristeva, J. (1982), Powers of Horror: An Essay on Abjection, Columbia University Press, New York.

Kuasirikun, N. (2011), "The portrayal of gender in annual reports in Thailand", Critical Perspectives on Accounting, Vol. 22, No. 1, pp. 53-78 .

Lacan, J. (1979), The Four Fundamental Concepts of Psychoanalysis, (A. Sheridan, Trans.), Horgarth, Harmondsworth, UK.

Livesey, S.M. (2002), "The Discourse of the Middle Ground", Management Communication Quarterly, Vol. 15, No 3, pp. 313-349.

Milne, M. J., Kearins, K., and Walton, S. (2006). "Creating Adventures in Wonderland: The Journey Metaphor and Environmental Sustainability", Organization, Vol. 13, No 6, pp. 801-839.

Milne, M. J., Tregidga, H., and Walton, S. (2009), "Words not actions! The ideological role of sustainable development reporting", Accounting, Auditing \& Accountability Journal, Vol. 22, No 8, pp. 1211-1257.

NCC (2016), Natural Capital Protocal Principles and Framework, available at: http://naturalcapitalcoalition.org/wp-content/uploads/2016/07/Framework_Book_2016-07-01-2.pdf, accessed 3 August 2016.

Phillips, M. (2014), "Re-Writing Corporate Environmentalism: Ecofeminism, Corporeality and the Language of Feeling”. Gender, Work \& Organization, Vol. 21, No 5, p. 443-458.

Plumwood, V. (1991), "Nature, self and gender: feminism, environmental philosophy and the critique of rationalism”, Hypatia, Vol. 6, No 1, pp. 3-27.

Plumwood, V. (1993), Feminism and the Mastery of Nature. Routledge, London. 
Porter, M.E., and Kramer, M.R., (2011), “Creating Shared Value”, Harvard Business Review, Vol. 89, No 1-2, pp. 62-77.

Prasad, P., and M. Elmes. (2005), "In the Name of the Practical: Unearthing the Hegemony of Pragmatics in the Discourse of Environmental Management", Journal of Management Studies, Vol. 42, No 4, pp. 845-867.

Preston, A. M., Wright, C., and Young J. J. (1996), "Imag[in]ing annual reports", Accounting, Organizations and Society, Vol. 21, No 1, pp. 113-137.

Preston, A., and Young, J., (2000), "Constructing the global corporation and corporate constructions of the global: A picture essay”, Accounting, Organizations and Society, Vol. 25, No 4-5, pp. $427-$ 449 .

Roberts, J. (2001), "Trust and control in Anglo-American systems of corporate governance: The individualising and socializing effects of processes of accountability", Human Relations, Vol. 54, No 12, pp. 1547-1572.

Roberts, J. (2009), "No one is perfect: The limits of transparency and an ethic for "intelligent" accountability", Accounting, Organizations and Society, Vol. 34, No 8, pp. 957-970.

Schutz, A. (1962), Collected Papers, Vol. I., The Problem of Social Reality, Nijhoff, The Hague.

Thompson, L. J. (2008), "Gender equity and corporate social responsibility in a post-feminist era". Business Ethics: A European Review, Vol. 17, No 1, pp. 87-106.

Tinker, T., and Neimark, M. (1987), "The role of annual reports in gender and class contradictions at general motors: 1917-1976”, Accounting, Organizations and Society, Vol. 12, No 1, pp. 71-88

World Economic Forum (2015), Outlook on the Global Agenda, accessed at http://reports.weforum.org/outlook-global-agenda-2015/top-10-trends-of-2015/1-deepening-incomeinequality/, 4 August, 2016 
